Published in final edited form as:

Curr Immunol Rev. 2013 August 1; 9(3): 120-128.

\title{
Parasites: what are they good for?
}

\author{
Jason S. Stumhofer ${ }^{1,3}$ and P'ng Loke ${ }^{2}$ \\ ${ }^{1}$ Department of Microbiology and Immunology, University of Arkansas for Medical Sciences, Little \\ Rock, AR 72205 \\ ${ }^{2}$ Department of Microbiology, New York University School of Medicine, New York, NY 10010
}

\begin{abstract}
Parasitic diseases caused by helminth and protozoan infections remain one of the largest global public health problems for mankind. While natural immunity in man is rare or slow to develop for many parasites, the immune response is capable of recognizing and responding to infection by utilizing a number of different immunological mechanisms. This special topics journal issue examines many of the key findings in the recent literature regarding the immune response against helminth and protozoan infections, as well as highlighting areas in which our current knowledge falls short. The question of how we can tailor immune responses to prevent or reduce disease burden is a burning question within the field of immunoparasitology.
\end{abstract}

\section{Keywords}

alternatively activated macrophages; B cells; innate lymphoid cells; helminth; parasite; protozoan; T cells; Toll-like receptors

\begin{abstract}
Parasitic diseases are caused by a number of protozoa (e.g. Plasmodium spp., Toxoplasma, Trypanosoma spp., and Leishmania spp.), and helminth worm (e.g. nematodes, trematodes, and cestodes) species. These diseases remain a major health burden in tropical and subtropical regions around the globe. There are many contributing factors for this, including the geographic range of the insect vectors that transmit many of these pathogens, access to healthcare, as well as insufficient attempts and funds for eradication campaigns. Millions of people remain infected, leading to chronic debilitating disease, disfigurement, and often death. Drugs are available for treatment or prevention of many parasitic infections, but they come at significant cost. The drugs often produce debilitating side effects, are difficult to attain or afford by the resident population that are most likely to be afflicted, and parasite resistance to effective therapeutics is spreading. Furthermore, commercially available vaccines to prevent parasitic diseases have not been developed due to the complexity of the parasite's lifecycle or multistage development, their multicellular composition (e.g. helminths), and antigenic variability. Despite these issues many scientific inroads have been made over the last decade to understand the unique, complex relationship between parasites and their host. Genomes have been sequenced, novel drug targets have been identified, and progress has been made in the development of vaccines for malaria and leishmaniasis [1-3]. The accompanying review articles will highlight some of these advances with a specific focus on Toll-like receptors (TLRs), innate lymphoid cells (ILCs), alternatively activated
\end{abstract}

\footnotetext{
${ }^{3}$ Corresponding author Jason S. Stumhofer, University of Arkansas for Medical Sciences, Department of Microbiology and Immunology, 4301 W. Markham St., Slot 511, Little Rock AR, 72205., jstumhofer@uams.edu, Phone: (501) 526-6180, Fax: (501) 686-5359.
}

Conflict of Interest

The authors have declared that no conflict of interest exists. 
macrophages, chemokines, $\mathrm{CD}^{+} \mathrm{T}$ cells, $\mathrm{T}$ and $\mathrm{B}$ cell exhaustion, and memory $\mathrm{T}$ cells. The accompanying articles, as well as a few additional topics covered in this introduction, will discuss the scientific breakthroughs that have furthered our understanding of the host immune response against protozoan and helminth parasites.

Parasites gain entry into their host through three major routes: fecal-oral (e.g. roundworms, Giardia, Cryptosporidium, and Toxoplasma), direct penetration of the skin (e.g. schistosomes and hookworms), and transmission into the skin by the bite of an insect vector (Plasmodium, Leishmania, Trypansoma, and filarial worms). The infection may be localized at the point of entry, or the parasite may disseminate to other organs either directly or indirectly via infection of migrating cell populations (e.g. red blood cells and antigenpresenting cells), resulting in pathology in many tissues, including the gastrointestinal tract, spleen, brain, liver, skin, bladder, heart and lungs. Due to the various routes of entry and sites of dissemination, these pathogens induce a myriad of host immunological responses within multiple tissues, including innate, cellular and humoral responses. The host immune response is capable of recognizing, containing, and controlling parasite replication and tissue damage, yet rarely eliminates or provides long-term protection after a single exposure to the parasite. Understanding successful evasion of immunity by parasites is a major goal that has challenged researchers in the field of immunoparasitology. Parasites can avoid immune recognition by varying the expression of surface antigens (e.g. African trypanosomes and Plasmodium falciparum), changing its developmental form or tissue tropism, replicating within leukocytes, or in the case of worms, through expression of surface tegument that prevents antibody or complement from binding.

The immune response to protozoans and helminths involves cells of the innate and adaptive immune system, although the type of immune response activated by each group of parasites is different. A T helper type $1\left(\mathrm{~T}_{\mathrm{H}} 1\right)$ response characterized by the production of interferon$\gamma($ IFN- $\gamma)$ is generated against protozoans, while helminth infections induce a $\mathrm{T}_{\mathrm{H}} 2$ response resulting in interleukin-4 (IL-4), IL-5 and IL-13 production. Detection of pathogens by the immune system is fostered by a limited number of receptors known as pattern recognition receptors (PRRs) that recognize conserved features common to many pathogens, which are referred to as pathogen-associated molecular patterns (PAMPs) [4]. PRRs are expressed by innate as well as non-hematopoietic cells, and can be localized to the cell surface, or found within the cytoplasm or endosomal vesicles. TLRs, which are a class of PRRs, have been shown to recognize PAMPs of protozoans (Figure 1; Reviewed by Ghosh and Stumhofer in this issue). While parasite-derived PAMPs have been shown to bind select TLRs and induce the production of pro-inflammatory cytokines in vitro, defining the role of these TLRs in promoting an inflammatory response in vivo has been less straightforward. For instance, infection of mice that are deficient in only a single TLR gene rarely results in a phenotypic change after infection, indicating the participation of multiple PRRs in the recognition of protozoan parasites in vivo. Additionally in the case of Plasmodium infection, multiple groups have reported contradicting results using the same TLR-deficient mice and Plasmodium species [5-9], which have further complicated our understanding of the contribution of PRRs in generating a protective or pathologic immune response during malaria infection.

Recently, there has been substantial progress in identifying parasite-derived PAMPs and the PRRs that recognize them [10-12]. For instance, TLR-11 and -12 have been shown to bind Toxoplasma gondii profilin as homo- or heterodimers [10,13,14]. While these TLRs are responsible for recognizing $T$. gondii infection in mice, TLR-11 and TLR-12 are not expressed in humans; therefore, other PRRs are involved in detecting this parasite infection in man. In support of this idea, Andrade et al. illustrated that Toxoplasma-derived DNA and RNA was capable of inducing pro-inflammatory cytokine production by human peripheral 
blood monocytes, suggesting that nucleic-acid sensing TLRs (TLR-7, -8, -9) associated with the endosome are key for sensing this infection in humans [14]. Although significant progress has been made in this area many parasitic PAMPs remain undefined, particularly regarding Leishmania and Trypansoma infection. Furthermore, involvement of PRRs in recognizing and generating a $\mathrm{T}_{\mathrm{H}} 2$ response against helminths remains a mystery. It is possible that sterile tissue damage provides the trigger for generating $\mathrm{T}_{\mathrm{H}} 2$ responses during helminth infection through mechanisms that do not require PRRs.

Coffman and Mosmann initially defined subsets of T helper cells based on their cytokine secretion pattern [15], but recently it has become clear that in addition to T cells ILCs are also important sources of cytokines. ILCs have been subdivided into three subsets - group 1 ILCs (comprising natural killer (NK) cells and ILC1s), group 2 ILCs (comprising ILC2s) and group 3 ILCs (comprising ILC3s and lymphoid tissue inducers) - based on their ability to produce type 1 , type 2 or $\mathrm{T}_{\mathrm{H}} 17$-associated cytokines. While some ILCs such as NK cells have been shown to be an important source of IFN- $\gamma$ in a number of protozoan infections [16-19] the role of additional ILC populations in the immune response to protozoan infections has not been widely explored. On the other hand, the role of ILCs in the immune response to helminth infections is better defined (Reviewed by Antignano and Zaph in this issue). For instance, infection with the worm Nippostrongylus brasiliensis resulted in identification of ILC2s in the intestine (Figure 2) [20-22]. These ILC2s were shown to secrete IL-5 and IL-13, and were critical for the induction of a $\mathrm{T}_{\mathrm{H}} 2$ response. How ILC2s directly or indirectly promote a $\mathrm{T}_{\mathrm{H}} 2$ response remains unclear, indicating that researchers have only begun to scratch the surface of elucidating the function of ILCs not only after parasitic infections, but also after exposure to other inflammatory stimuli or during normal tissue homeostasis.

Another important innate cell type that has recently received significant attention - the macrophage - contributes not only to clearance of pathogens and removal of cellular debris, but also plays a role in tissue homeostasis. Macrophage populations have recently been categorized into different subsets based largely on cell surface marker expression and gene expression profiles. These subsets include classically activated macrophages (CAMacs), alternatively activated macrophages (AAMacs), tumor-associated macrophages and regulatory macrophages [23]. CAMacs, which are derived from monocytes recruited from the blood to the site of infection during an inflammatory $\mathrm{T}_{\mathrm{H}} 1$ response exhibit microbicidal properties. These CAMacs play an essential role in the clearance of many intracellular protozoan pathogens, and are often targeted by many parasites (e.g. Leishmania, Toxoplasma, Trypanosoma cruzi) in order to promote their growth and survival within the host.

AAMacs, the counterpart of CAMacs, are induced by $\mathrm{T}_{\mathrm{H}} 2$ associated cytokines such as IL-4, IL-13 and IL-33. AAMacs express several signature proteins, including the mannose receptor, Arginase 1, chitinases and RELMa [24], and contribute to the immune response against helminth parasites by promoting wound healing (Reviewed by Jang and Nair in this issue). Interestingly, in a model of Litomosoides sigmodontis infection, AAMacs were not found to be derived from the blood in response to infection, but instead accumulated in response to IL-4 mediated proliferation of tissue-resident macrophages [25]. Whether these AAMacs are derived solely through proliferation, or can be recruited and differentiated from blood monocytes is unknown, but under active investigation by numerous groups. While their primary function after helminth infections may be to limit and repair tissue damage caused by the worms, the role of AAMacs in $\mathrm{T}_{\mathrm{H}} 1$ responses may differ. For instance, during chronic T. gondii infection production of chitinases by AAMacs in the brain serve to lyse chitin-rich cysts, exposing parasites to immune-mediated killing by other effector cells [26]. 
Alternatively, some protozoan parasites actively promote AAMac differentiation in order to promote their survival [27-29].

A major contribution to the field of immunology from the study of parasitic infections has been their use in defining classical $\mathrm{T}_{\mathrm{H}} 1$ and $\mathrm{T}_{\mathrm{H}} 2$ responses, and the cytokines associated with these responses $\left(\mathrm{T}_{\mathrm{H}} 1\right.$ : IL-12, IFN- $\gamma$; $\mathrm{T}_{\mathrm{H}} 2$ : IL-4, IL-5, IL-13). Moreover, these models continue to yield new information about the function of recently described cytokines such as IL-22, IL-25, IL-27 and IL-33. IL-22, which has primarily been shown to have a protective role in the gut by mediating barrier integrity and production of antimicrobial proteins [30], was also shown to contribute to ileitis associated with oral T. gondii infection [31, 32]. IL-25 and IL-33, which are epithelial derived cytokines, are instrumental in promoting a $\mathrm{T}_{\mathrm{H}} 2$ response after Trichuris muris or $N$. brasiliensis infection. The ability of these cytokines to influence the development of $\mathrm{T}_{\mathrm{H}} 2$ polarized $\mathrm{CD}^{+} \mathrm{T}$ cells after these infections lies in their capacity to induce expansion and differentiation of innate cell populations. [20-22, 33, 34].

Another cytokine that has received scrutiny over the last ten years is IL-17, due to its association with immunopathology in chronic diseases [35, 36]. Production of IL-17 is primarily attributed to $\mathrm{T}_{\mathrm{H}} 17$ cells and group $3 \mathrm{ILCs}$; however, a recent study indicated that, following infection with T. cruzi, B cells are capable of secreting this cytokine [37]. Interestingly, IL-17 production by B cells occurs independently of B cell receptor signaling during $T$. cruzi infection. Instead, the trans-sialidase protein of the parasite modifies glycoproteins on the B cell surface, including the tyrosine phosphatase CD45, resulting in activation of cell-signaling pathways that lead to IL-17A and IL-17F production.

Furthermore, these IL-17 producing B cells were shown to be necessary for control of $T$. cruzi infection in mice. Moreover, IL-17 production has been detected in a number of parasitic infections, and has been found to either contribute to parasite control or promote immune-mediated pathology [38-42].

Parasites primarily induce chronic disease; therefore, these pathogens have served as useful models for understanding immunoregulation, particularly the mediators that dampen inflammation and the cells that produce them. For instance, the IL-6 family member IL-27, which is produced by dendritic cells and $\mathrm{M} \varphi s$, has been shown to be a crucial cytokine involved in limiting $\mathrm{T}_{\mathrm{H}} 1, \mathrm{~T}_{\mathrm{H}} 2$ and $\mathrm{T}_{\mathrm{H}} 17$ inflammatory responses after parasitic infections [43-48]. In addition to directly inhibiting cytokine production by T cells, IL-27 can also induce regulatory $\mathrm{T}$ cell populations during $T$. gondii infection [49], and promote production of IL-10 by CD4 ${ }^{+}$T cells after T. gondii, L. major and $P$. chabaudi infection $[44,50,51]$ to limit immunopathology.

In addition to understanding the effector function of $\mathrm{T}$ cells, there has been increasing interest in identifying the sites where lymphocytes are primed after parasitic infections, and how lymphocytes are recruited to infected tissues. For example, it was long thought that the liver served as the primary site for activation of Plasmodium liver stage-specific $\mathrm{CD}^{+} \mathrm{T}$ cells; however, it is now understood that the skin draining lymph node at the site of Plasmodium sporozoite inoculation plays an important role in the priming of $\mathrm{CD}^{+} \mathrm{T}$ cell responses and this priming is adequate to induce protective immunity against sporozoite challenge $[52,53]$ (Reviewed by Villarino and Schmidt in this issue). Also, the advent of intravital microscopy has provided an opportunity to observe the behavior of $\mathrm{T}$ cells and other immune cells in vivo after infection. This has been particularly useful in understanding how $\mathrm{CD}^{+}$and $\mathrm{CD}^{+}{ }^{+} \mathrm{T}$ cells are recruited to and move within infected tissues, such as the liver and brain, as well as how these cells may recognize and kill infected cells [54-58].

One mechanism that the host employs to promote recruitment of immune cells to infected tissues is the use of chemokine gradients (Reviewed by McGovern and Wilson in this issue). 
Upon infection chemokine gradients serve to mark paths within tissues, guiding various immune cells to their designated targets. For example, CXCL9 and CXCL10 are upregulated in the brain during chronic Toxoplasma infection. These chemokines are involved in recruitment and retention of antigen-specific $\mathrm{CD} 8^{+} \mathrm{T}$ cells in the brain, and enhance the speed with which these cells find the location of their target [55]. CCL21 is also upregulated in the brain during chronic Toxoplasma infection and influences the migration of $\mathrm{CD} 4^{+} \mathrm{T}$ cells within this organ, promoting their migration from extraparenchymal sites to the parenchyma [58].

As mentioned, the end result of most parasitic infections is chronic disease, primarily due to the inability of the host to completely resolve the infection during the acute immune response. While the cell-mediated immune response is involved in controlling chronic parasitemia, the humoral immune response plays a critical role in limiting parasite replication during this stage of infection. In B cell deficient mice infected with Plasmodium spp., T. gondii, T. brucei, T. muris and L. major, the absence of B cells results in a significant increase in parasite burden during the chronic stage of infection, resulting in increased pathology and lethality in some cases [59-66]. Additionally, while B cell deficiency does not result in an increase in egg burden in the liver during Schistosoma mansoni infection, the absence of these lymphocytes does result in increased pathology in the liver, and an increase in egg burden and pathology in the lung [67, 68]. The observed phenotypes in B cell deficient mice are primarily due to the absence of antibody production; however, one cannot rule out additional effector functions of B cells in the immune response to these parasites such as activation of $\mathrm{CD} 4^{+} \mathrm{T}$ cells and production of cytokines that promote $\mathrm{T}_{\mathrm{H}} 1, \mathrm{~T}_{\mathrm{H}} 2$ or $\mathrm{T}_{\mathrm{H}} 17$ responses.

As a consequence of persistent infection, responding $\mathrm{T}$ cells begin to exhibit changes in their gene expression profile that lead to their functional impairment, a process known as $\mathrm{T}$ cell exhaustion [69]. Currently, most of our understanding of T cell exhaustion is based on the increased expression of co-inhibitory receptors such as PD-1, LAG-3, CD160, BTLA, CTLA-4 and Tim-3. These molecules are normally transiently upregulated on activated $\mathrm{T}$ cells after infection. However, in the face of persistent infection, expression of these molecules is sustained on $\mathrm{T}$ cells, thus negatively regulating their activity and allowing the infection to persist (Figure 3). There is evidence for T cell exhaustion after T. gondii, $T$. cruzi, L. major, S. mansoni and Plasmodium infection [70-77] (Reviewed by Zander and Butler in this issue). For example, simultaneous blockade of LAG3 and PD-1 resulted in enhanced clearance of blood-stage $P$. yoelii infection, which was correlated with an improved $\mathrm{T}_{\mathrm{H}} 1$ response and enhanced protective antibody production [75]. T cells express multiple co-inhibitory receptors on their surface, but the interplay of signaling through these receptors is largely unknown as are the molecular signatures of the $\mathrm{T}$ cells that are responding to chronic parasitic infection. Moreover, detailed information of the pathways that sustain the expression of these inhibitory receptors on $\mathrm{T}$ cells during chronic infection is sparse. Greater insight regarding these processes could yield potential avenues for manipulation of $\mathrm{T}$ cells during chronic disease to enhance protection and/or pathogen clearance. However, one has to wonder, particularly in the case of malaria infection, whether persistent antigen or repeated exposure is necessary for maintenance of clinical immunity.

T cells are not the only adaptive immune cells that are linked to a dysfunctional phenotype during chronic parasitic infections, as B cells also display impaired responses (Reviewed by Zander and Butler in this issue). These include polyclonal activation, deletion of B cell subsets and formation of atypical memory B cells (Figure 4). All of these B cell impairments may contribute to the slow development of antibody-mediated immunity, especially in the case of malaria. Polyclonal B cell activation occurs during rodent and human malaria, resulting in hypergammaglobulinemia and depletion of B cell pools. The atypical memory B 
cells associated with malaria infection resemble the exhausted memory B cells observed in HIV-infected individuals [78], and are characterized by a hyporesponsive phenotype [79]. However, a recent study suggested that atypical memory B cells isolated from subjects in malaria endemic areas could competently secrete antibodies after stimulation, and neutralize P. falciparum infectivity in vitro [80], suggesting that these atypical B cells are functional and participate in an anti-Plasmodium response. However, whether this phenomenon occurs in vivo has yet to be demonstrated.

Although significant progress has been made in our understanding of parasitic diseases and the subsequent immune response, there is still much to be learned. No effective vaccine is available to prevent or reduce disease burden for the major protozoan infections, including malaria, or helminth infections. One of the major hurdles that exist in vaccine development is determining what approach - be it parasite derived antigens, attenuated whole parasites or another method - will be necessary to induce protective $\mathrm{CD} 4^{+}$and $\mathrm{CD} 8^{+} \mathrm{T}$ cells and antibody in order to provide complete protection upon challenge (Reviewed by Villarino and Schmidt in this issue). Another barrier that has to be approached in order to develop effective vaccines is determining what type(s) of memory $\mathrm{T}$ cell populations are formed during chronic parasitic infections, and whether stable populations of memory $\mathrm{T}$ cells can be maintained in the absence of antigen in order to afford protection against these infections (Reviewed by Opata and Stephens in this issue). Vaccine trials in humans and rodents have indicated that immunity wanes with time after vaccination or treatment of infection [81-84], suggesting that continual exposure to antigen is required to maintain protection against malaria, Leishmania and other chronic infections [85, 86]. However, in the case of Leishmania infection in mice, long-lived central memory $\mathrm{CD}^{+} \mathrm{T}$ cells are generated after infection and can persist in the absence of antigen [87], indicating that a vaccine capable of expanding these cells might provide long-term protection. Moreover, our ability to successfully design anti-parasitic vaccines will be greatly aided by our continued efforts to define mechanisms by which parasites undermine the immune response to establish chronic infection. Therefore, a more thorough understanding of the basic immunology of the mouse and human responses to these infections is needed, particularly regarding how protective $\mathrm{T}$ and $\mathrm{B}$ cell responses are initiated and maintained.

\section{Acknowledgments}

Work in the Stumhofer laboratory is supported by grants from the NIH (AI090179), NIGMS Center for Microbial Pathogenesis and Host Inflammatory Responses COBRE at UAMS (GM103625) and the Arkansas Biosciences Institute, the major research component of the Arkansas Tobacco Settlement Proceeds Act of 2000. Work in the Loke laboratory is supported by grants from the NIH (AI093811 and AI094166), the Broad Medical Research Program of The Broad Foundation, and the Kevin and Masha Keating Family Foundation.

\section{List of Abbreviations}

$\begin{array}{ll}\text { TLR } & \text { Toll-like receptor } \\ \text { ILC } & \text { Innate lymphoid cell } \\ \text { PRR } & \text { Pattern recognition receptor } \\ \text { PAMP } & \text { Pathogen associated molecular pattern } \\ \text { CAMacs } & \text { Classically activated macrophages } \\ \text { AAMacs } & \text { Alternatively activated macrophages }\end{array}$




\section{References}

1. Agnandji ST, Lell B, Fernandes JF, Abossolo BP, Methogo BG, Kabwende AL, et al. A phase 3 trial of RTS,S/AS01 malaria vaccine in African infants. N Engl J Med. 2012; 367(24):2284-2295. [PubMed: 23136909]

2. Seder RA, Chang LJ, Enama ME, Zephir KL, Sarwar UN, Gordon IJ, et al. Protection against malaria by intravenous immunization with a nonreplicating sporozoite vaccine. Science. 2013; 341(6152):1359-1365. [PubMed: 23929949]

3. First Vaccine Against Fatal Visceral Leishmaniasis Enter Clinical Trial. 2012. [2-22-12];Available from: http://www.idri.org/press-2-22-12.php.

4. Kumar H, Kawai T, Akira S. Pathogen recognition by the innate immune system. Int Rev Immunol. 2011; 30(1):16-34. [PubMed: 21235323]

5. Coban C, Ishii KJ, Uematsu S, Arisue N, Sato S, Yamamoto M, et al. Pathological role of Toll-like receptor signaling in cerebral malaria. Int Immunol. 2007; 19(1):67-79. [PubMed: 17135446]

6. Lepenies B, Cramer JP, Burchard GD, Wagner H, Kirschning CJ, Jacobs T. Induction of experimental cerebral malaria is independent of TLR2/4/9. Med Microbiol Immunol. 2008; 197(1): 39-44. [PubMed: 17668237]

7. Togbe D, Schofield L, Grau GE, Schnyder B, Boissay V, Charron S, et al. Murine cerebral malaria development is independent of toll-like receptor signaling. Am J Pathol. 2007; 170(5):1640-1648. [PubMed: 17456769]

8. Cramer JP, Lepenies B, Kamena F, Holscher C, Freudenberg MA, Burchard GD, et al. MyD88/ IL-18-dependent pathways rather than TLRs control early parasitaemia in non-lethal Plasmodium yoelii infection. Microbes Infect. 2008; 10(12-13):1259-1265. [PubMed: 18692153]

9. Gowda NM, Wu X, Gowda DC. TLR9 and MyD88 are crucial for the development of protective immunity to malaria. J Immunol. 2012; 188(10):5073-5085. [PubMed: 22516959]

10. Yarovinsky F, Zhang D, Andersen JF, Bannenberg GL, Serhan CN, Hayden MS, et al. TLR11 activation of dendritic cells by a protozoan profilin-like protein. Science. 2005; 308(5728):16261629. [PubMed: 15860593]

11. Coban C, Ishii KJ, Kawai T, Hemmi H, Sato S, Uematsu S, et al. Toll-like receptor 9 mediates innate immune activation by the malaria pigment hemozoin. J Exp Med. 2005; 201(1):19-25. [PubMed: 15630134]

12. Krishnegowda G, Hajjar AM, Zhu J, Douglass EJ, Uematsu S, Akira S, et al. Induction of proinflammatory responses in macrophages by the glycosylphosphatidylinositols of Plasmodium falciparum: cell signaling receptors, glycosylphosphatidylinositol (GPI) structural requirement, and regulation of GPI activity. J Biol Chem. 2005; 280(9):8606-8616. [PubMed: 15623512]

13. Koblansky AA, Jankovic D, Oh H, Hieny S, Sungnak W, Mathur R, et al. Recognition of profilin by Toll-like receptor 12 is critical for host resistance to Toxoplasma gondii. Immunity. 2013; 38(1):119-130. [PubMed: 23246311]

14. Andrade WA, Souza Mdo C, Ramos-Martinez E, Nagpal K, Dutra MS, Melo MB, et al. Combined action of nucleic acid-sensing Toll-like receptors and TLR11/TLR12 heterodimers imparts resistance to Toxoplasma gondii in mice. Cell Host Microbe. 2013; 13(1):42-53. [PubMed: 23290966]

15. Mosmann TR, Cherwinski H, Bond MW, Giedlin MA, Coffman RL. Two types of murine helper T cell clone. I. Definition according to profiles of lymphokine activities and secreted proteins. J Immunol. 1986; 136(7):2348-2357. [PubMed: 2419430]

16. Mohan K, Moulin P, Stevenson MM. Natural killer cell cytokine production, not cytotoxicity, contributes to resistance against blood-stage Plasmodium chabaudi AS infection. J Immunol. 1997; 159(10):4990-4998. [PubMed: 9366426]

17. Sher A, Oswald IP, Hieny S, Gazzinelli RT. Toxoplasma gondii induces a T-independent IFNgamma response in natural killer cells that requires both adherent accessory cells and tumor necrosis factor-alpha. J Immunol. 1993; 150(9):3982-3989. [PubMed: 8473745]

18. Laskay T, Rollinghoff M, Solbach W. Natural killer cells participate in the early defense against Leishmania major infection in mice. Eur J Immunol. 1993; 23(9):2237-2241. [PubMed: 8370404] 
19. Scharton TM, Scott P. Natural killer cells are a source of interferon gamma that drives differentiation of CD4+ T cell subsets and induces early resistance to Leishmania major in mice. $\mathrm{J}$ Exp Med. 1993; 178(2):567-577. [PubMed: 8101861]

20. Price AE, Liang HE, Sullivan BM, Reinhardt RL, Eisley CJ, Erle DJ, et al. Systemically dispersed innate IL-13-expressing cells in type 2 immunity. Proc Natl Acad Sci U S A. 2010; 107(25): 11489-11494. [PubMed: 20534524]

21. Neill DR, Wong SH, Bellosi A, Flynn RJ, Daly M, Langford TK, et al. Nuocytes represent a new innate effector leukocyte that mediates type-2 immunity. Nature. 2010; 464(7293):1367-1370. [PubMed: 20200518]

22. Moro K, Yamada T, Tanabe M, Takeuchi T, Ikawa T, Kawamoto H, et al. Innate production of $\mathrm{T}(\mathrm{H}) 2$ cytokines by adipose tissue-associated c-Kit(+)Sca-1(+) lymphoid cells. Nature. 2010; 463(7280):540-544. [PubMed: 20023630]

23. Murray PJ, Wynn TA. Protective and pathogenic functions of macrophage subsets. Nat Rev Immunol. 2011; 11(11):723-737. [PubMed: 21997792]

24. Stein M, Keshav S, Harris N, Gordon S. Interleukin 4 potently enhances murine macrophage mannose receptor activity: a marker of alternative immunologic macrophage activation. J Exp Med. 1992; 176(1):287-292. [PubMed: 1613462]

25. Jenkins SJ, Ruckerl D, Cook PC, Jones LH, Finkelman FD, van Rooijen N, et al. Local macrophage proliferation, rather than recruitment from the blood, is a signature of TH2 inflammation. Science. 2011; 332(6035):1284-1288. [PubMed: 21566158]

26. Nance JP, Vannella KM, Worth D, David C, Carter D, Noor S, et al. Chitinase dependent control of protozoan cyst burden in the brain. PLoS Pathog. 2012; 8(11):e1002990. [PubMed: 23209401]

27. Kane MM, Mosser DM. The role of IL-10 in promoting disease progression in leishmaniasis. J Immunol. 2001; 166(2):1141-1147. [PubMed: 11145695]

28. Osorio EY, Zhao W, Espitia C, Saldarriaga O, Hawel L, Byus CV, et al. Progressive visceral leishmaniasis is driven by dominant parasite-induced STAT6 activation and STAT6-dependent host arginase 1 expression. PLoS Pathog. 2012; 8(1):e1002417. [PubMed: 22275864]

29. Jensen KD, Wang Y, Wojno ED, Shastri AJ, Hu K, Cornel L, et al. Toxoplasma polymorphic effectors determine macrophage polarization and intestinal inflammation. Cell Host Microbe. 2011; 9(6):472-483. [PubMed: 21669396]

30. Zheng Y, Valdez PA, Danilenko DM, Hu Y, Sa SM, Gong Q, et al. Interleukin-22 mediates early host defense against attaching and effacing bacterial pathogens. Nat Med. 2008; 14(3):282-289. [PubMed: 18264109]

31. Wilson MS, Feng CG, Barber DL, Yarovinsky F, Cheever AW, Sher A, et al. Redundant and pathogenic roles for IL-22 in mycobacterial, protozoan, and helminth infections. J Immunol. 2010; 184(8):4378-4390. [PubMed: 20220096]

32. Munoz M, Heimesaat MM, Danker K, Struck D, Lohmann U, Plickert R, et al. Interleukin (IL)-23 mediates Toxoplasma gondii-induced immunopathology in the gut via matrixmetalloproteinase-2 and IL-22 but independent of IL-17. J Exp Med. 2009; 206(13):3047-3059. [PubMed: 19995958]

33. Saenz SA, Siracusa MC, Monticelli LA, Ziegler CG, Kim BS, Brestoff JR, et al. IL-25 simultaneously elicits distinct populations of innate lymphoid cells and multipotent progenitor type 2 (MPPtype2) cells. J Exp Med. 2013; 210(9):1823-1837. [PubMed: 23960191]

34. Saenz SA, Siracusa MC, Perrigoue JG, Spencer SP, Urban JF Jr, Tocker JE, et al. IL25 elicits a multipotent progenitor cell population that promotes $\mathrm{T}(\mathrm{H}) 2$ cytokine responses. Nature. 2010; 464(7293):1362-1366. [PubMed: 20200520]

35. McGeachy MJ, Cua DJ. The link between IL-23 and Th17 cell-mediated immune pathologies. Semin Immunol. 2007; 19(6):372-376. [PubMed: 18319054]

36. Ghoreschi K, Laurence A, Yang XP, Hirahara K, O'Shea JJ. T helper 17 cell heterogeneity and pathogenicity in autoimmune disease. Trends Immunol. 2011; 32(9):395-401. [PubMed: 21782512]

37. Bermejo DA, Jackson SW, Gorosito-Serran M, Acosta-Rodriguez EV, Amezcua-Vesely MC, Sather BD, et al. Trypanosoma cruzi trans-sialidase initiates a program independent of the transcription factors RORgammat and Ahr that leads to IL-17 production by activated B cells. Nat Immunol. 2013; 14(5):514-522. [PubMed: 23563688] 
38. Ishida H, Imai T, Suzue K, Hirai M, Taniguchi T, Yoshimura A, et al. IL-23 protection against Plasmodium berghei infection in mice is partially dependent on IL-17 from macrophages. Eur J Immunol. 2013; 43(10):2696-2706. [PubMed: 23843079]

39. Lopez Kostka S, Dinges S, Griewank K, Iwakura Y, Udey MC, von Stebut E. IL-17 promotes progression of cutaneous leishmaniasis in susceptible mice. J Immunol. 2009; 182(5):3039-3046. [PubMed: 19234200]

40. Rutitzky LI, Bazzone L, Shainheit MG, Joyce-Shaikh B, Cua DJ, Stadecker MJ. IL-23 is required for the development of severe egg-induced immunopathology in schistosomiasis and for lesional expression of IL-17. J Immunol. 2008; 180(4):2486-2495. [PubMed: 18250458]

41. Rutitzky LI, Lopes da Rosa JR, Stadecker MJ. Severe CD4 T cell-mediated immunopathology in murine schistosomiasis is dependent on IL-12p40 and correlates with high levels of IL-17. J Immunol. 2005; 175(6):3920-3926. [PubMed: 16148138]

42. Zhang Y, Chen L, Gao W, Hou X, Gu Y, Gui L, et al. IL-17 neutralization significantly ameliorates hepatic granulomatous inflammation and liver damage in Schistosoma japonicum infected mice. Eur J Immunol. 2012; 42(6):1523-1535. [PubMed: 22678906]

43. Stumhofer JS, Laurence A, Wilson EH, Huang E, Tato CM, Johnson LM, et al. Interleukin 27 negatively regulates the development of interleukin 17-producing $\mathrm{T}$ helper cells during chronic inflammation of the central nervous system. Nat Immunol. 2006; 7(9):937-945. [PubMed: 16906166]

44. Anderson CF, Stumhofer JS, Hunter CA, Sacks D. IL-27 regulates IL-10 and IL-17 from CD4+ cells in nonhealing Leishmania major infection. J Immunol. 2009; 183(7):4619-4627. [PubMed: 19748991]

45. Artis D, Johnson LM, Joyce K, Saris C, Villarino A, Hunter CA, et al. Cutting edge: early IL-4 production governs the requirement for IL-27-WSX-1 signaling in the development of protective Th1 cytokine responses following Leishmania major infection. J Immunol. 2004; 172(8):46724675. [PubMed: 15067040]

46. Villarino A, Hibbert L, Lieberman L, Wilson E, Mak T, Yoshida H, et al. The IL-27R (WSX-1) is required to suppress T cell hyperactivity during infection. Immunity. 2003; 19(5):645-655. [PubMed: 14614852]

47. Artis D, Villarino A, Silverman M, He W, Thornton EM, Mu S, et al. The IL-27 receptor (WSX-1) is an inhibitor of innate and adaptive elements of type 2 immunity. J Immunol. 2004; 173(9): 5626-5634. [PubMed: 15494513]

48. Findlay EG, Greig R, Stumhofer JS, Hafalla JC, de Souza JB, Saris CJ, et al. Essential role for IL-27 receptor signaling in prevention of Th1-mediated immunopathology during malaria infection. J Immunol. 2010; 185(4):2482-2492. [PubMed: 20631310]

49. Hall AO, Beiting DP, Tato C, John B, Oldenhove G, Lombana CG, et al. The cytokines interleukin 27 and interferon-gamma promote distinct Treg cell populations required to limit infectioninduced pathology. Immunity. 2012; 37(3):511-523. [PubMed: 22981537]

50. Stumhofer JS, Silver JS, Laurence A, Porrett PM, Harris TH, Turka LA, et al. Interleukins 27 and 6 induce STAT3-mediated T cell production of interleukin 10. Nat Immunol. 2007; 8(12):13631371. [PubMed: 17994025]

51. Freitas do Rosario AP, Lamb T, Spence P, Stephens R, Lang A, Roers A, et al. IL-27 promotes IL-10 production by effector Th1 CD4+ T cells: a critical mechanism for protection from severe immunopathology during malaria infection. J Immunol. 2012; 188(3):1178-1190. [PubMed: 22205023]

52. Obeid M, Franetich JF, Lorthiois A, Gego A, Gruner AC, Tefit M, et al. Skin-draining lymph node priming is sufficient to induce sterile immunity against pre-erythrocytic malaria. EMBO Mol Med. 2013; 5(2):250-263. [PubMed: 23255300]

53. Chakravarty S, Cockburn IA, Kuk S, Overstreet MG, Sacci JB, Zavala F. CD8+ T lymphocytes protective against malaria liver stages are primed in skin-draining lymph nodes. Nat Med. 2007; 13(9):1035-1041. [PubMed: 17704784]

54. Cockburn IA, Amino R, Kelemen RK, Kuo SC, Tse SW, Radtke A, et al. In vivo imaging of CD8+ T cell-mediated elimination of malaria liver stages. Proc Natl Acad Sci U S A. 2013; 110(22): 9090-9095. [PubMed: 23674673] 
55. Harris TH, Banigan EJ, Christian DA, Konradt C, Tait Wojno ED, Norose K, et al. Generalized Levy walks and the role of chemokines in migration of effector CD8+ T cells. Nature. 2012; 486(7404):545-548. [PubMed: 22722867]

56. John B, Harris TH, Tait ED, Wilson EH, Gregg B, Ng LG, et al. Dynamic Imaging of CD8(+) T cells and dendritic cells during infection with Toxoplasma gondii. PLoS Pathog. 2009; 5(7):e1000505. [PubMed: 19578440]

57. Wilson EH, Harris TH, Mrass P, John B, Tait ED, Wu GF, et al. Behavior of parasite-specific effector CD8+ T cells in the brain and visualization of a kinesis-associated system of reticular fibers. Immunity. 2009; 30(2):300-311. [PubMed: 19167248]

58. Ploix CC, Noor S, Crane J, Masek K, Carter W, Lo DD, et al. CNS-derived CCL21 is both sufficient to drive homeostatic CD4+ T cell proliferation and necessary for efficient CD4+ T cell migration into the CNS parenchyma following Toxoplasma gondii infection. Brain Behav Immun. 2011; 25(5):883-896. [PubMed: 20868739]

59. Langhorne J, Cross C, Seixas E, Li C, von der Weid T. A role for B cells in the development of T cell helper function in a malaria infection in mice. Proceedings of the National Academy of Sciences of the United States of America. 1998; 95(4):1730-1734. [PubMed: 9465085]

60. von der Weid T, Honarvar N, Langhorne J. Gene-targeted mice lacking B cells are unable to eliminate a blood stage malaria infection. Journal of immunology. 1996; 156(7):2510-2516.

61. von der Weid T, Langhorne J. Altered response of CD4+ T cell subsets to Plasmodium chabaudi chabaudi in B cell-deficient mice. Int Immunol. 1993; 5(10):1343-1348. [PubMed: 8268139]

62. Weinbaum FI, Evans CB, Tigelaar RE. Immunity to Plasmodium Berghei yoelii in mice. I. The course of infection in T cell and B cell deficient mice. Journal of immunology. 1976; 117(5 Pt. 2): 1999-2005.

63. Magez S, Schwegmann A, Atkinson R, Claes F, Drennan M, De Baetselier P, et al. The role of Bcells and IgM antibodies in parasitemia, anemia, and VSG switching in Trypanosoma bruceiinfected mice. PLoS Pathog. 2008; 4(8):e1000122. [PubMed: 18688274]

64. Blackwell NM, Else KJ. B cells and antibodies are required for resistance to the parasitic gastrointestinal nematode Trichuris muris. Infect Immun. 2001; 69(6):3860-3868. [PubMed: 11349052]

65. Kang H, Remington JS, Suzuki Y. Decreased resistance of B cell-deficient mice to infection with Toxoplasma gondii despite unimpaired expression of IFN-gamma, TNF-alpha, and inducible nitric oxide synthase. J Immunol. 2000; 164(5):2629-2634. [PubMed: 10679102]

66. Woelbing F, Kostka SL, Moelle K, Belkaid Y, Sunderkoetter C, Verbeek S, et al. Uptake of Leishmania major by dendritic cells is mediated by Fcgamma receptors and facilitates acquisition of protective immunity. J Exp Med. 2006; 203(1):177-188. [PubMed: 16418399]

67. Fairfax KC, Amiel E, King IL, Freitas TC, Mohrs M, Pearce EJ. IL-10R blockade during chronic schistosomiasis mansoni results in the loss of B cells from the liver and the development of severe pulmonary disease. PLoS Pathog. 2012; 8(1):e1002490. [PubMed: 22291593]

68. Ferru I, Roye O, Delacre M, Auriault C, Wolowczuk I. Infection of B-cell-deficient mice by the parasite Schistosoma mansoni: demonstration of the participation of B cells in granuloma modulation. Scand J Immunol. 1998; 48(3):233-240. [PubMed: 9743206]

69. Wherry EJ. T cell exhaustion. Nat Immunol. 2011; 12(6):492-499. [PubMed: 21739672]

70. Bhadra R, Gigley JP, Khan IA. PD-1-mediated attrition of polyfunctional memory CD8+ T cells in chronic toxoplasma infection. J Infect Dis. 2012; 206(1):125-134. [PubMed: 22539813]

71. Bhadra R, Gigley JP, Weiss LM, Khan IA. Control of Toxoplasma reactivation by rescue of dysfunctional CD8+ T-cell response via PD-1-PDL-1 blockade. Proc Natl Acad Sci U S A. 2011; 108(22):9196-9201. [PubMed: 21576466]

72. Albareda MC, Laucella SA, Alvarez MG, Armenti AH, Bertochi G, Tarleton RL, et al. Trypanosoma cruzi modulates the profile of memory CD8+ T cells in chronic Chagas' disease patients. Int Immunol. 2006; 18(3):465-471. [PubMed: 16431876]

73. Mou Z, Muleme HM, Liu D, Jia P, Okwor IB, Kuriakose SM, et al. Parasite-derived arginase influences secondary anti-Leishmania immunity by regulating programmed cell death-1-mediated CD4+ T cell exhaustion. J Immunol. 2013; 190(7):3380-3389. [PubMed: 23460745] 
74. Adler G, Steeg C, Pfeffer K, Murphy TL, Murphy KM, Langhorne J, et al. B and T lymphocyte attenuator restricts the protective immune response against experimental malaria. J Immunol. 2011; 187(10):5310-5319. [PubMed: 21998455]

75. Butler NS, Moebius J, Pewe LL, Traore B, Doumbo OK, Tygrett LT, et al. Therapeutic blockade of PD-L1 and LAG-3 rapidly clears established blood-stage Plasmodium infection. Nat Immunol. 2012; 13(2):188-195. [PubMed: 22157630]

76. Taylor JJ, Krawczyk CM, Mohrs M, Pearce EJ. Th2 cell hyporesponsiveness during chronic murine schistosomiasis is cell intrinsic and linked to GRAIL expression. J Clin Invest. 2009; 119(4):1019-1028. [PubMed: 19258704]

77. van der Werf N, Redpath SA, Azuma M, Yagita H, Taylor MD. Th2 cell-intrinsic hyporesponsiveness determines susceptibility to helminth infection. PLoS Pathog. 2013; 9(3):e1003215. [PubMed: 23516361]

78. Moir S, Ho J, Malaspina A, Wang W, DiPoto AC, O'Shea MA, et al. Evidence for HIV-associated B cell exhaustion in a dysfunctional memory B cell compartment in HIV-infected viremic individuals. J Exp Med. 2008; 205(8):1797-1805. [PubMed: 18625747]

79. Weiss GE, Crompton PD, Li S, Walsh LA, Moir S, Traore B, et al. Atypical memory B cells are greatly expanded in individuals living in a malaria-endemic area. J Immunol. 2009; 183(3):21762182. [PubMed: 19592645]

80. Muellenbeck MF, Ueberheide B, Amulic B, Epp A, Fenyo D, Busse CE, et al. Atypical and classical memory B cells produce Plasmodium falciparum neutralizing antibodies. J Exp Med. 2013; 210(2):389-399. [PubMed: 23319701]

81. Olotu A, Fegan G, Wambua J, Nyangweso G, Awuondo KO, Leach A, et al. Four-year efficacy of RTS,S/AS01E and its interaction with malaria exposure. N Engl J Med. 2013; 368(12):1111-1120. [PubMed: 23514288]

82. Freitas do Rosario AP, Muxel SM, Rodriguez-Malaga SM, Sardinha LR, Zago CA, CastilloMendez SI, et al. Gradual decline in malaria-specific memory T cell responses leads to failure to maintain long-term protective immunity to Plasmodium chabaudi AS despite persistence of B cell memory and circulating antibody. J Immunol. 2008; 181(12):8344-8355. [PubMed: 19050251]

83. Achtman AH, Stephens R, Cadman ET, Harrison V, Langhorne J. Malaria-specific antibody responses and parasite persistence after infection of mice with Plasmodium chabaudi chabaudi. Parasite Immunol. 2007; 29(9):435-444. [PubMed: 17727567]

84. Guinovart C, Aponte JJ, Sacarlal J, Aide P, Leach A, Bassat Q, et al. Insights into long-lasting protection induced by RTS,S/AS02A malaria vaccine: further results from a phase IIb trial in Mozambican children. PLoS One. 2009; 4(4):e5165. [PubMed: 19365567]

85. Stephens R, Langhorne J. Effector memory Th1 CD4 T cells are maintained in a mouse model of chronic malaria. PLoS Pathog. 2010; 6(11):e1001208. [PubMed: 21124875]

86. Scott P, Artis D, Uzonna J, Zaph C. The development of effector and memory T cells in cutaneous leishmaniasis: the implications for vaccine development. Immunol Rev. 2004; 201:318-338. [PubMed: 15361250]

87. Zaph C, Uzonna J, Beverley SM, Scott P. Central memory T cells mediate long-term immunity to Leishmania major in the absence of persistent parasites. Nat Med. 2004; 10(10):1104-1110. [PubMed: 15448686] 


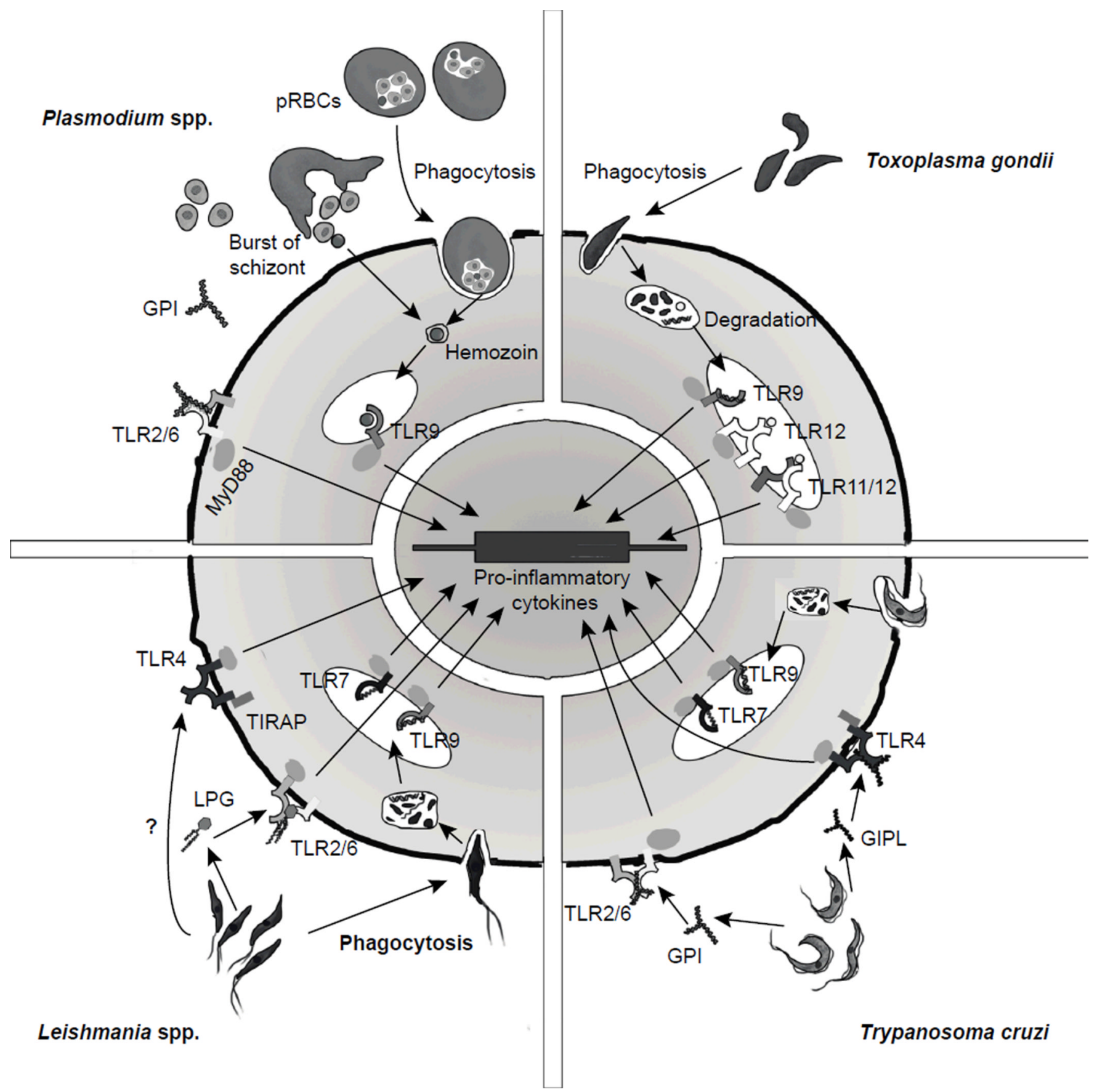

Figure 1. Recognition of protozoan PAMPs by host TLRs

Infection of host by the protozoan parasites (Clockwise from the top): T. gondii, T. cruzi, Leishmania spp., and Plasmodium spp. results in the detection of distinct parasite derived PAMPs, including GPIs, hemozoin, nucleic acids, etc., by TLRs expressed on the cell membrane and within the endosome. Binding of parasite-derived PAMPs to TLRs results in the activation of MyD88-dependent and -independent signaling pathways that lead to the transcription of pro-inflammatory cytokines, chemokines, type I interferons and antimicrobial proteins. Question mark denotes the undefined TLR-4 ligand of Leishmania. 

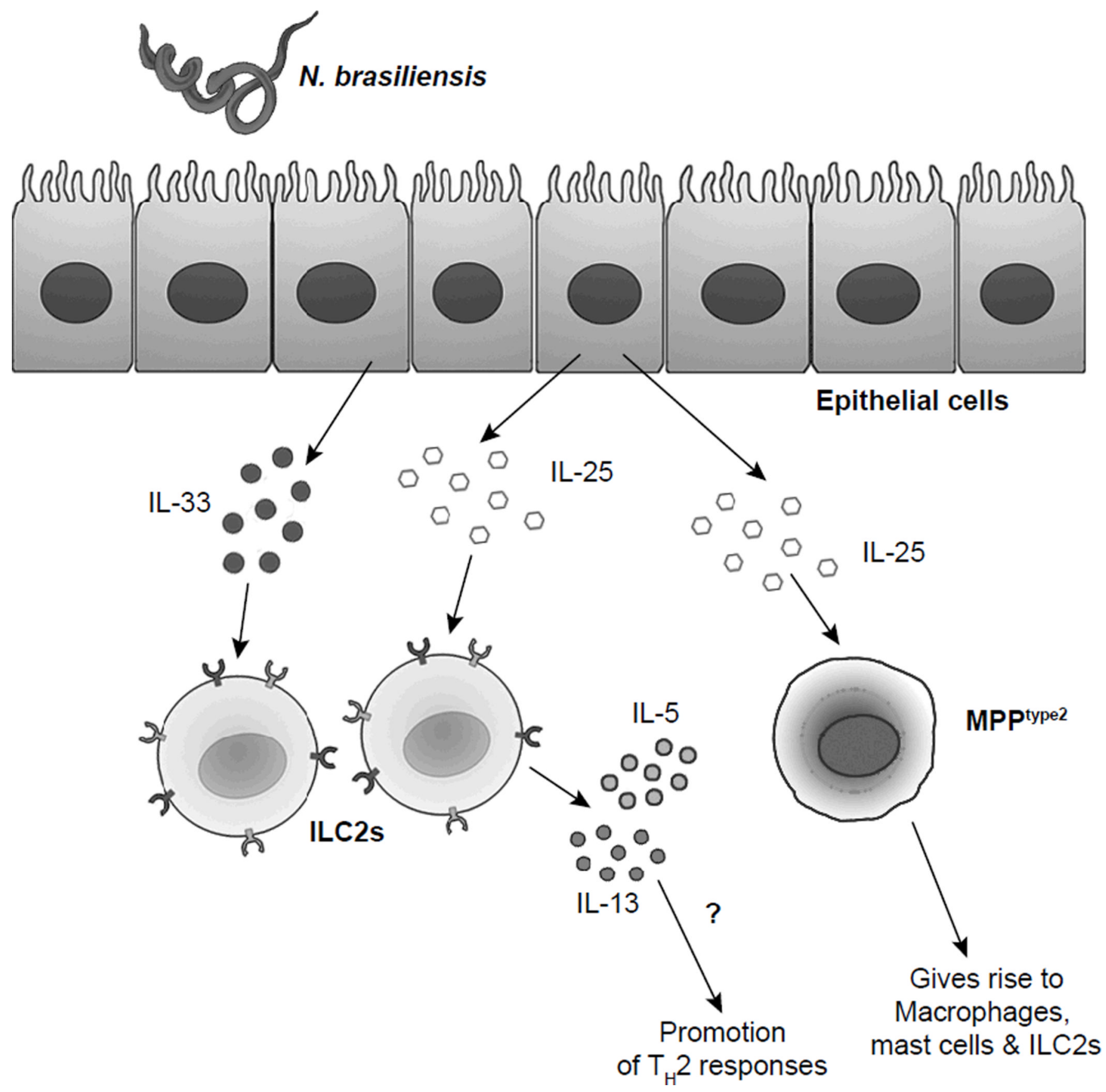

Figure 2. Infection with $N$. brasiliensis results in the production of ILC populations within the intestine

Infection with the roundworm $N$. brasiliensis triggers production of the cytokines IL-25 and IL-33 by epithelial cells in the gut. These cytokines promote the production of type 2 innate lymphoid cells (ILC2s), which are capable of producing the $\mathrm{T}_{\mathrm{H}} 2$ cytokines IL-5 and IL-13, leading to the promotion of $\mathrm{a}_{\mathrm{H}} 2$ response. However, it is still unclear as to how and if ILC2s are necessary for the development of a $\mathrm{T}_{\mathrm{H}} 2$ response after worm infection. Additionally, the cytokine IL-25 can promote the development of another innate cell population known as MPPtype ${ }^{2}$ cells. These progenitor cells can subsequently differentiate 
into a number of leukocyte populations associated with $\mathrm{T}_{\mathrm{H}} 2$ responses, including macrophages, mast cells and ILC2s. 
Up-regulated

expression of

PD-1 and CTLA-4

$$
\circ \circ
$$
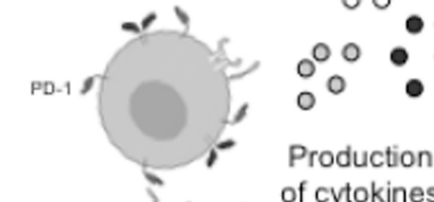

$\begin{array}{r}\circ \\ \hline\end{array}$

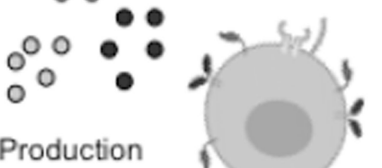

PD-1:PD-L1

Production

CTLA.

of cytokines

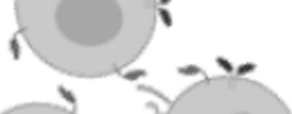

interaction

induce

apoptosis

and deletion

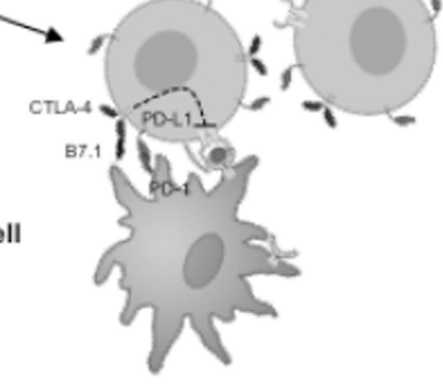

Pre-activated $\mathrm{CD}_{4}{ }^{+} \mathrm{T}$-cell

Up-regulated

expression of PD-1

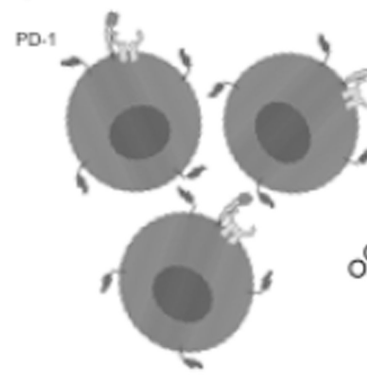

Pre-activated cytotoxic $\mathrm{CD} 8+\mathrm{T}$-cell

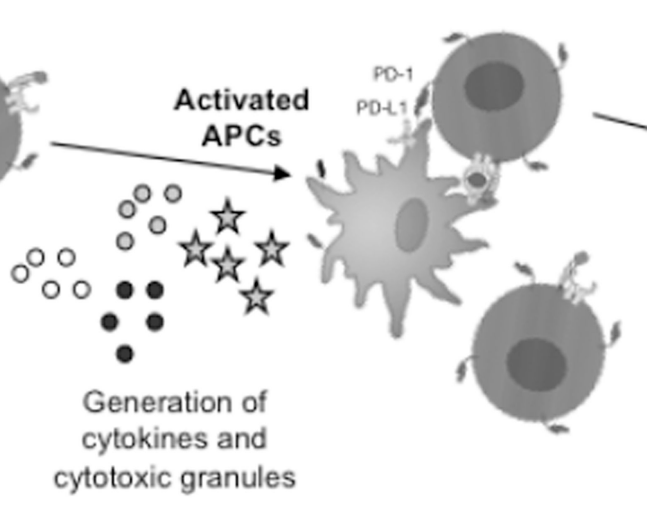

Generation of ytotoxic granules

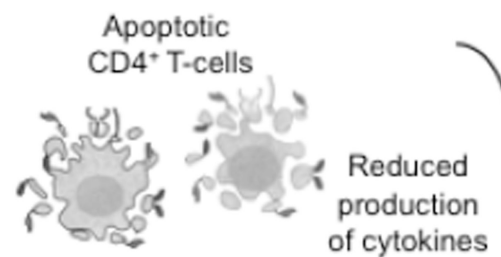

production
of cytokines
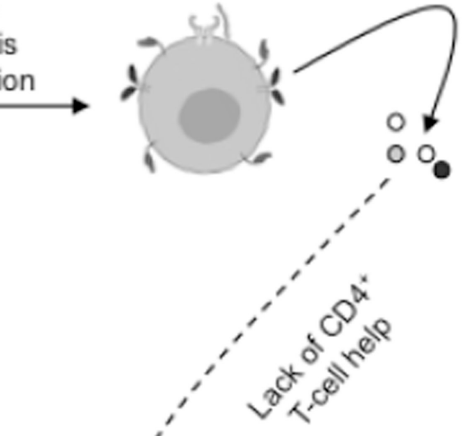

Figure 3. T cell exhaustion during parasitic infections leads to a persistent chronic infection that cannot be fully resolved

$\mathrm{CD}^{+}$and $\mathrm{CD}^{+} \mathrm{T}$ cells responding to persistent infections, as is the case for most parasitic infections, exhibit alterations in their transcriptional profile, which leads to functional impairments (i.e. decreased cytokine production) and increased rates of apoptosis as part of a process collectively known as T cell exhaustion. Sustained expression of co-inhibitory receptors such as PD-1 and CTLA-4 by T cells during chronic infection negatively regulates the activity of $\mathrm{T}$ cells and promotes pathogen persistence. 


\section{A. Polyclonal B-cell Activation}

\section{Dendritic Cells}

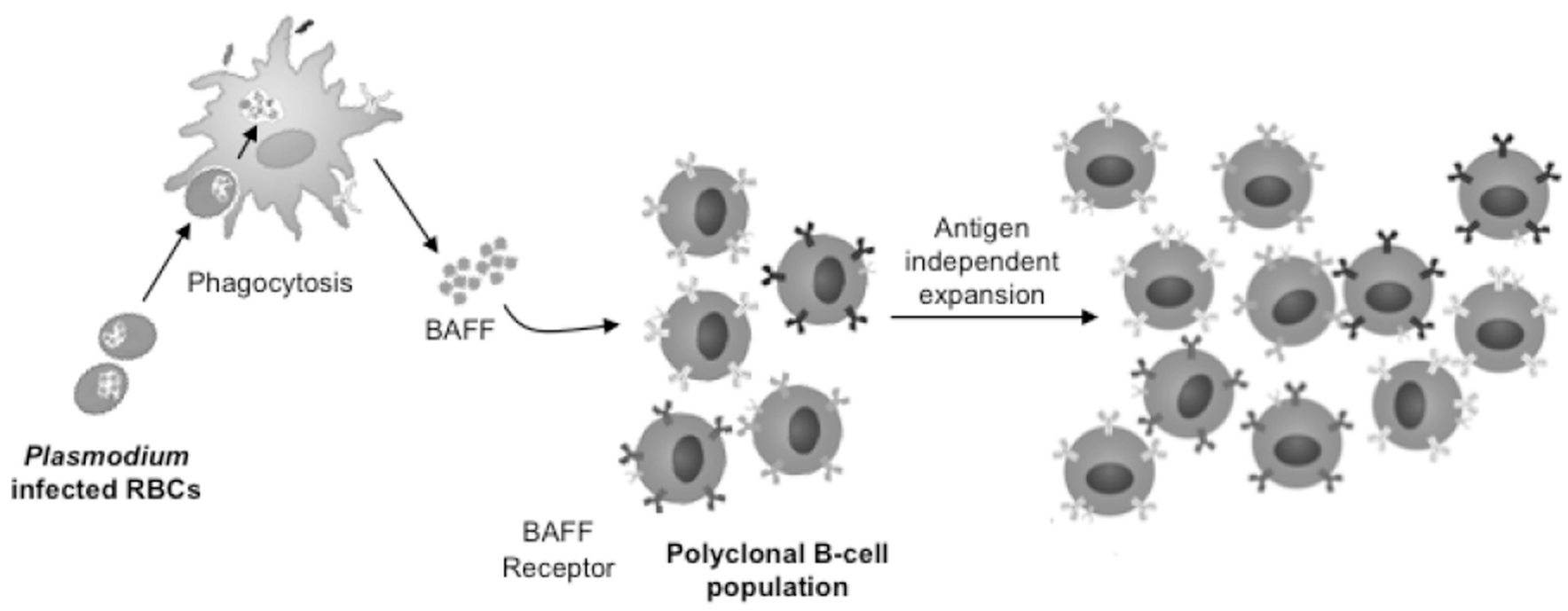

\section{B. Atypical memory B-cell Expansion}

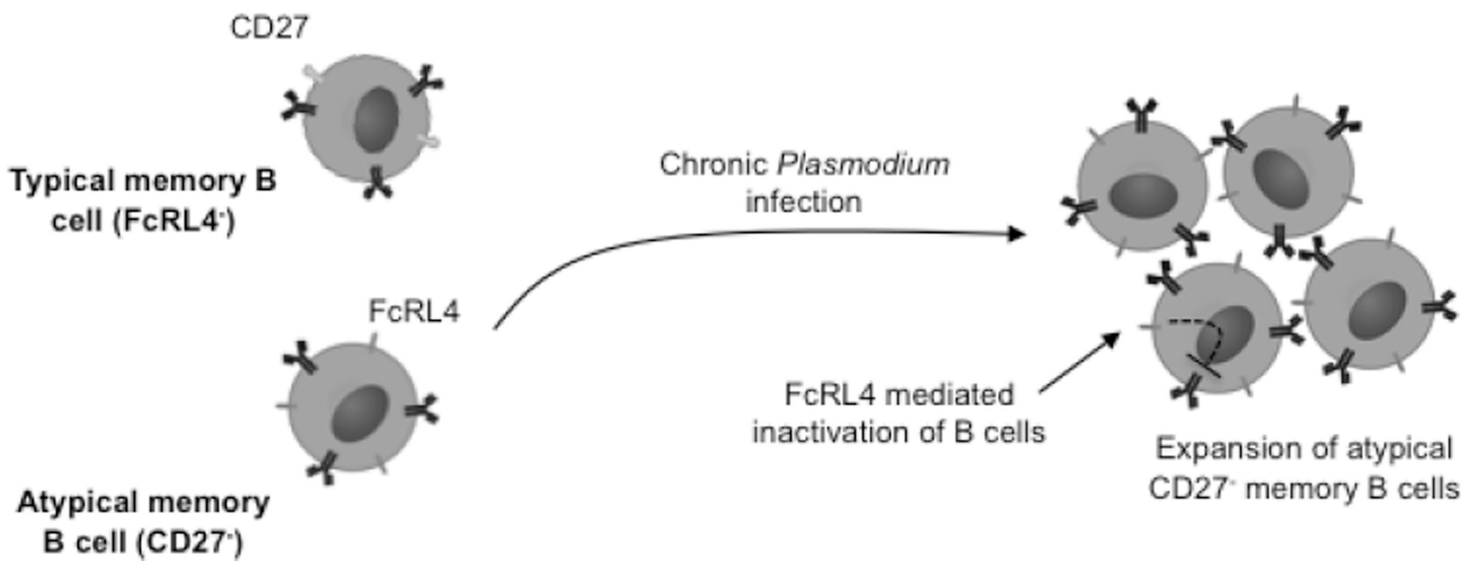

Figure 4.

Plasmodium infection leads to polyclonal B cell activation and expansion of an atypical memory B cell population, which contribute to B cell dysfunction

A.) Infection of the host by Plasmodium can trigger the production of soluble factors such as BAFF by dendritic cells. BAFF can subsequently promote antigen-independent proliferation of naïve and transitional B cells, which may contribute to immune-pathology. B.) $P$. falciparum infection in humans causes the expansion of a population of hypo-responsive memory B cells known as "atypical memory" B cells characterized by the expression of an inhibitory receptor FcRL4. Ligation of the BCR and FcLR4 has been shown to impair B cell activation. 